Primljen / Received: 15.5.2016. Ispravljen / Corrected: 19.1.2017.

Prihvaćen / Accepted: 14.4.2017. Dostupno online / Available online: 30.12.2018.

\title{
Effects of point loads on membrane structures
}

\section{Authors:}

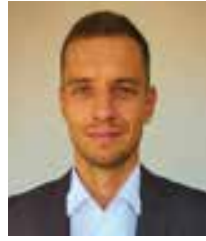

Assist.Prof. Vuk Milošević, PhD. Arh

University of Nis, Serbia

Faculty of Civil Engineering and Architecture vukamer@yahoo.com

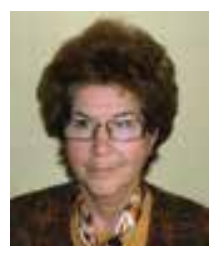

Prof. Biserka Marković, PhD. Arh

University of Nis, Serbia

Faculty of Civil Engineering and Architecture bisam@gaf.ni.ac.rs

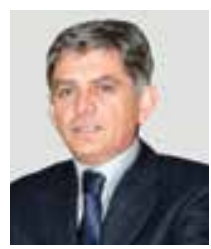

Prof. Dragoslav Stojić, PhD. CE

University of Nis, Serbia

Faculty of Civil Engineering and Architecture dragoslav.stojic@gaf.ni.ac.rs

\section{Vuk Milošević, Biserka Marković, Dragoslav Stojić}

\section{Effects of point loads on membrane structures}

A research focusing on the effects of point load on membrane structures is presented in the paper. The research was conducted on a numerical model of a typical membrane structure. Different point loads were applied to the model, and several structural parameters were monitored so as to define membrane behaviour under point load. The results show that point loads influence membrane structures in a significantly different way compared to area loads. The main repercussions of point loads on the membrane structure are the change in geometry of the structure and the change of membrane forces.

\section{Key words:}

membrane structures, point loads, lightweight structures, geometry change, membrane forces, tensile structures

Prethodno priopćenje

\section{Vuk Milošević, Biserka Marković, Dragoslav Stojić}

\section{Utjecaj točkastog opterećenja na membranske konstrukcije}

U radu je prikazano istraživanje utjecaja točkastog opterećenja na membranske konstrukcije. Istraživanje je provedeno na numeričkom modelu tipične membranske konstrukcije. Modelom su obuhvaćena razna točkasta opterećenja, a analizirano je nekoliko parametara konstrukcije kako bi se odredilo ponašanje membrane pri djelovanju točkastog opterećenja. Dobiveni rezultati pokazuju da točkasto opterećenje utječe na membranske konstrukcije znatno drugačije nego što je to slučaj kod površinskog opterećenja. Glavni utjecaji točkastog opterećenja na membransku konstrukciju su promjena geometrije konstrukcije te promjena membranskih sila.

Ključne riječi:

membranske konstrukcije, točkasta opterećenja, lake konstrukcije, promjena geometrije, membranske sile, vlačne konstrukcije

Vorherige Mitteilung

\section{Vuk Milošević, Biserka Marković, Dragoslav Stojić}

\section{Einfluss der Punktbelastung auf Membrankonstruktionen}

In der Abhandlung wird die Untersuchung des Einflusses der Punktbelastung auf Membrankonstruktionen aufgezeigt. DieUntersuchungwurdeaneinem nummerischen Modell einer typischen Membrankonstruktion durchgeführt. Unterschiedliche Punktbelastungen wurden mit dem Modell einbezogen und mehrere Konstruktionsparameter wurden analysiert, um das Verhalten der Membran bei Wirkung der Punktbelastung zu bestimmen. Die erhaltenen Ergebnisse zeigen, dass sich die Punktbelastung im Wesentlichen anders auf die Membrankonstruktion auswirkt, als es der Fall bei der Oberflächenbelastung ist. Die Hauptwirkungen der Punktbelastung auf die Membrankonstruktion sind die Änderung der Geometrie der Konstruktion sowie die Änderung der Membrankräfte. 


\section{Introduction}

Membrane structures are tensile surface structures that have been used worldwide since the mid-20th century. Their aesthetically most attractive feature is their double curved form. In order to be stable, they need to have a double curved form with negative Gaussian curvature, and to be constantly under tension. Membranes have an extremely low self-weight of about $1 \mathrm{~kg} / \mathrm{m}^{2}$, because of the small membrane thickness in the range of $1 \mathrm{~mm}$. Regardless of such lightweight and thin properties, membrane structures can span several dozens of meters. At the same time, they are completely prefabricated and their installation is not time-consuming. However, small membrane thickness results in unfavourable thermal properties. Because of this, they are most frequently used to cover open spaces. The application of membrane structures to enclose a space can result in a reduced energy efficiency, unless double membrane layers are used.

Membrane structures have been a topic of many scientific research projects in recent years. Several fields of investigation can be differentiated with regard to such structures. Most studies deal with the form of the membrane, as it is so different compared to other structures. The main issue about the form is the form-finding [1], which is a process of obtaining the form of the structure, based on some given conditions. The same process is also investigated regarding cable net structures [2]. Another geometrical problem is the mapping of the membrane surface onto membrane material [3]. This process is necessary for obtaining a double curved surface from planar pieces of material. Different types of materials are used for the construction of membrane structures [4]. Properties of membrane materials are also an important field of research [5]. Although many studies have been published about membrane structures, there are very few that investigate the effects of point loads. Milosevic [6] investigated the dependence of membrane deflection on the position and intensity of point loads. Selvadurai [7] investigated the correlation between the point load and deflections of a small rubber membrane. The effects of different prestress intensities on the displacement of membrane structures under point load have also been researched [8]. The influence of the membrane structure shape on displacements under point load has also been investigated [9]. However, a comprehensive understanding of all effects of point load on membrane structures has, to the authors' knowledge, still not been attained.

The aim of this paper is to investigate effects that point loads have on membrane structures. The research should help in gaining better understanding on the consequences of point load actions. So far, point loads have not been systematically introduced in the structural analysis of membrane structures. The American standard [10] and European design guide for tensile surface structures [11] do not thoroughly address the issue of point load exerted on membrane structures. This results in uncertainties during structural analysis. Engineers include point loads in calculations based on previous experience, or they simply fail to consider the effects of point loads. This can have serious consequences on the structure, and can even lead to structural failure. Due to specific properties of membranes, they exhibit different behaviour under point loads compared to more conventional structures. The research presented in this paper should serve as a step towards implementing point load actions into standards relating to membrane structures.

\section{Methodology}

The research presented in this paper was conducted on a numerical model of a typical membrane structure. The structure represented by models is saddle shaped, it has a square floor plan with the side size of $10 \mathrm{~m}$, while the difference in height between the lower and upper supports is $3 \mathrm{~m}$. The warp and weft directions are parallel to the diagonals of the structure, while the warp is oriented from one lower support to the other. The

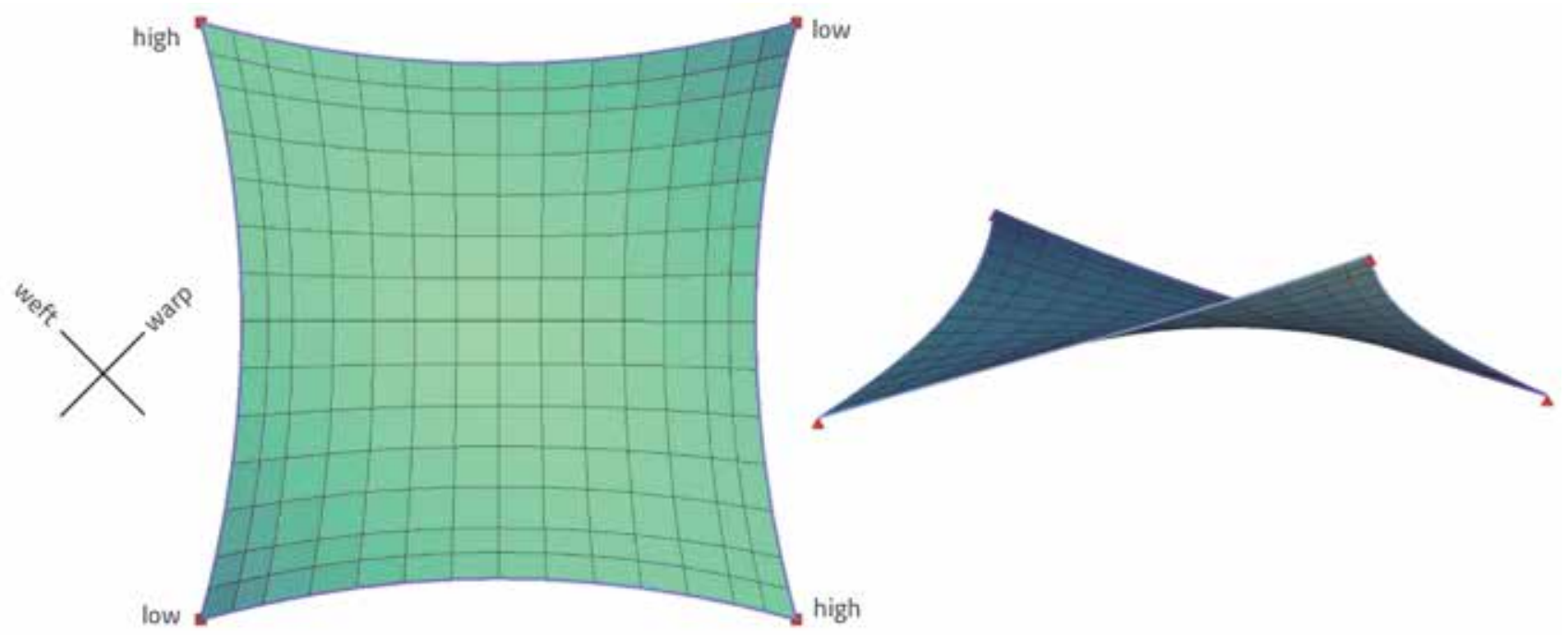

Figure 1. Plan and perspective of numerical model 
membrane has a thickness of $1 \mathrm{~mm}$. The modules of elasticity of membrane material are $500 \mathrm{~N} / \mathrm{mm}^{2}$ in warp, and $375 \mathrm{~N} / \mathrm{mm}^{2}$ in weft directions. The shear module is $5 \mathrm{~N} / \mathrm{mm}^{2}$ and the Poisson ratio is 0.2 . The supports are fixed and connected with $19 \mathrm{~mm}$ diameter cables at the edges of the membrane. During the formfinding the cables have a prestress of $20 \mathrm{kN}$, and the membrane has a prestress of $1 \mathrm{kN} / \mathrm{m}$ in both warp and weft directions. Formfinding and analysis of the numerical models is performed in the Sofistik 2012 software [12]. The numerical model of the structure is divided into 196 finite elements. The plan and perspective of the numerical model are shown in Figure 1.

In comparison to area loads, point loads act on membrane structures less frequently. Point loads are usually caused by workers maintaining, or experts inspecting the membrane. Typical area loads are snow load and wind load. The effects of area loads are considered in structural analysis in line with current standards. Based on experience with the effects of area loads on membrane structures, several parameters have been selected in order to monitor the behaviour of membrane structures under point loads. In this research, their behaviour is represented through the following parameters: change of membrane geometry, change of membrane forces in warp and weft directions, change of forces in edge cables, and change of supportreactions. The behaviour of thestructure under pointload is monitored and compared to the unloaded state. Conclusions on the effects of point loads on membrane structures are drawn based on the obtained results. The numerical model testing procedure was set so that every internal node was separately loaded with a point load. The intensity of the point load was kept constant at $1 \mathrm{kN}$, with a vertical downward direction. The results of the monitored parameters were recorded after each loading. The same structure was independently loaded with the area load of $0.6 \mathrm{kN} / \mathrm{m}^{2}$ in the vertical downward direction. The application area of the area load was varied, so that it simulated snow load when applied over the entire structure, while smaller areas of application were used for comparison with point loads. More than 28000 results that describe the changes of geometry of the membrane, more than 56000 results that describe the changes in membrane forces, about 9000 results that show the changes in forces in edge cables, and 676 results that show the changes of the support reactions, were collected in this way.

\section{Results and discussion}

The results of parametric analysis are presented and discussed separately for each monitored parameter. The effects of point load on the analysed parameters are correlated with the effects of area loads while the effects of point load importance are evaluated.

\subsection{Change of geometry}

External loads exerted on membrane structures result in the deflection of structures. These deflections can be regarded as a change of geometry of the membrane structure. The changes in geometry are only temporary, and last as long as the load is applied. Generally, these changes of geometry are much bigger in membrane structures compared to traditional building materials that have a much higher compression and bending stiffness than membranes. Solutions to large deflection of membranes are formulated through mathematical apparatus, e.g. [13]. Figure 2 shows changes of geometry of the analysed membrane structure under point load of $1 \mathrm{kN}$ acting at the centre of the membrane.

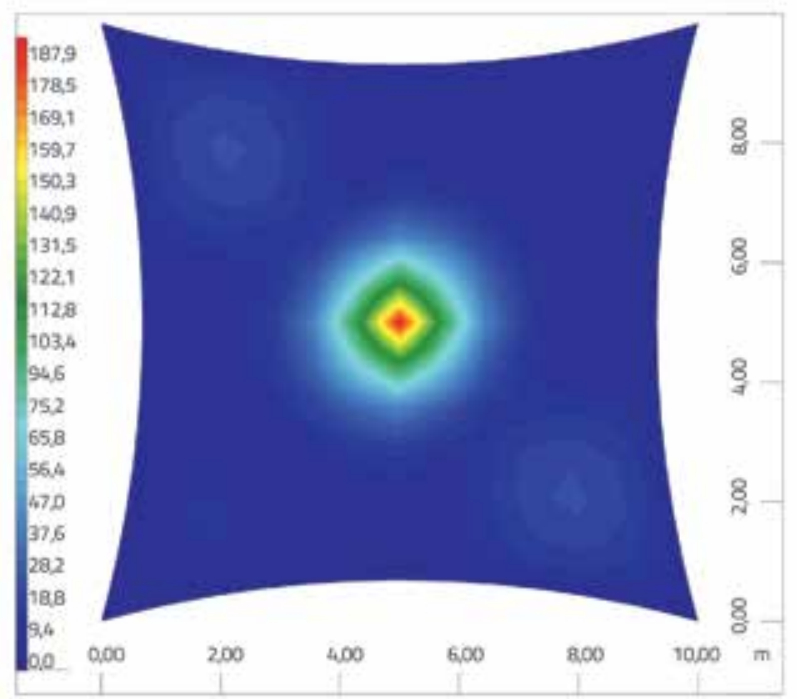

Figure 2. Changes of geometry of the membrane under point load of 1 $\mathbf{k N}$ at the centre of the structure $(\mathrm{mm})$

As shown in Figure 2, most large displacements are concentrated around the point where the load is applied. The results of the research show the same behaviour for every position where the point load is applied. This confirms conclusions made in previous studies [6], where it is stated that point loads produce localized changes in geometry when applied to membrane structures. However, for this research, the aspect of intensity of maximum geometry change is more important than its position. Figure 2 shows the displacement of $187.9 \mathrm{~mm}$ when the point load is applied to the centre of the membrane, while the highest displacement recorded in this research is $190.5 \mathrm{~mm}$. The behaviour of the membrane under point load is complex, and a detailed analysis of this behaviour is a part of a wider research. Deformations as well as other mechanical properties of the membrane material are dependent on the load history. Under the analysed point load, the strain at the position of the point load is $8 \%$. Thus, the material is past the crimp interchange phase, and strains are in the elastic zone. Figure 3 shows the dependence of maximum displacement on the intensity of point load applied to the centre of the membrane. The nonlinear relation between the load intensity and displacements can be observed. Figure 4 shows what the maximum displacements of 
the membrane in the global $Z$ direction would be under a point load of $1 \mathrm{kN}$ at that particular point.

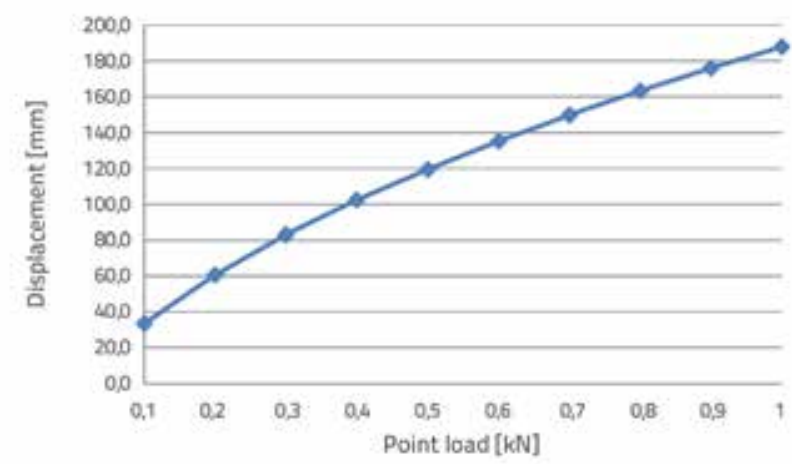

Figure 3. Maximum displacement for different intensity of point load acting in the centre of the membrane $(\mathrm{mm})$

The analysed structure with the span of $10 \mathrm{~m}$ is characterised by maximum displacements of almost $20 \mathrm{~cm}$ under the point load of $1 \mathrm{kN}$ only. Such behaviour would not be possible in any conventional structures made of concrete, steel or timber, or would lead to the conclusion that there is a serious malfunction of the structure. Maximum displacements of such structures under any loading combination are limited to about $\mathrm{L} / 350$, depending on the standards used, $\mathrm{L}$ being the span of the structure. The membrane structure does, nevertheless, have a displacement of L/50 under a simple point load of 1 $\mathrm{kN}$. This practically shows that the standards used for other structures are not applicable to membrane structures with regard to maximum displacements, and that specific rules for membrane structures must be implemented. The unwritten rule amongst the engineers designing membrane structures is that maximum displacements should not be higher than the $L / 10$ under any load case. Larger displacements can lead to serious discomfort of the users of the space enclosed or covered by the membrane. Even much smaller displacements can lead to ponding [14] which has already caused some of the lightweight structures to collapse. At the same time, there is a serious risk of membrane clashing with other surfaces, which can result in the damage to the membrane and the whole structure. Unfortunately, maximum displacements of membrane structures under external loads have not yet been limited by standards.

The area load of $0.6 \mathrm{kN} / \mathrm{m}^{2}$ applied over the entire structure analysed in this research produced the maximum deflection of about $370 \mathrm{~mm}$. This area load has a total of more than $50 \mathrm{kN}$ of load spread equally across the surface of the structure. If this area load is compared to the point load of $1 \mathrm{kN}$, it can be seen that the area load has more than 50 times larger load, and that the maximum deflection is less than 2 times larger. It can be concluded that the concentrated load is more efficient in producing larger deflections of membranes than the load spread across a larger area. This is explained by the membrane material properties and its negligible compression stiffness, which does not enable the external load to be counteracted by bending. Rather, the membrane suffers large geometry changes that allow for tension forces of the membrane to balance the internal and external forces. However, area loads have by nature much higher loads compared to the usual point loads, so that in the end area loads result in larger changes in geometry. The end result is that point loads with very low loads can produce deflections that are comparable to much larger area loads. This shows the importance of point loads with regard to changes in geometry. The changes in geometry of membrane structures under point loads are undoubtedly large, and as such present an important consequence of the point load action. This shows the need for taking into account point loads when verifying maximum displacements for ponding and structural clashes. If standards regulating maximum displacements of the membrane structures are to be defined in the future, point loads should certainly have a place in these standards.

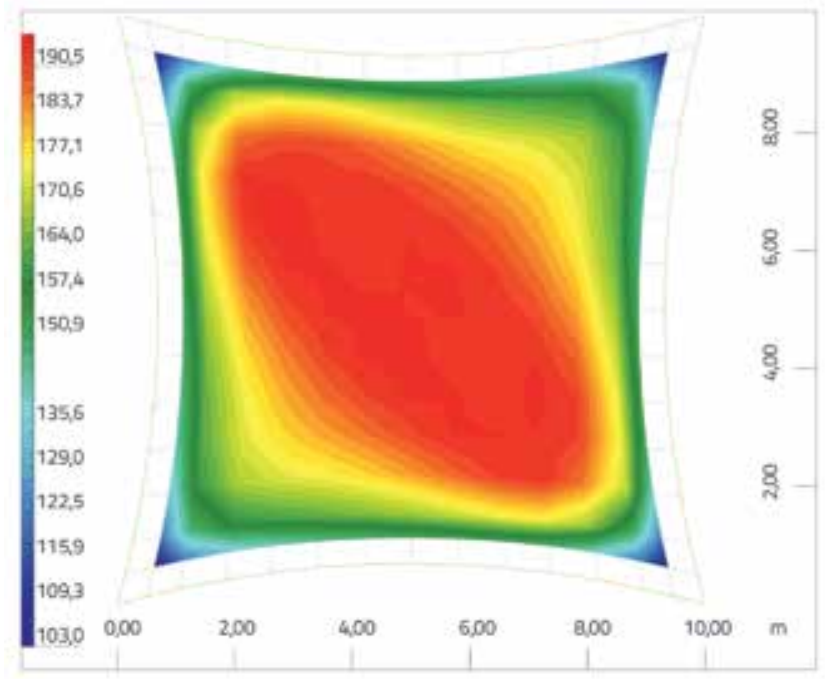

Figure 4. Membrane sensitivity to 1 kN point load, maximum displacement in global $Z(\mathrm{~mm})$

\subsection{Change of forces}

Three important parameters regarding forces were monitored during this research: membrane forces, cable forces, and support reactions. These parameters are crucial in selecting the appropriate type of membrane material and dimensioning of the edge cables and the supporting structure for the membrane.

\subsubsection{Membrane forces}

In membrane structures, membrane forces are represented as forces in warp and weft directions, because of the membrane material's orthotropic properties. They are introduced to the membrane by prestressing in the erection phase of the structure. In order for the membrane structure to be stable it needs to be constantly under tension. The 


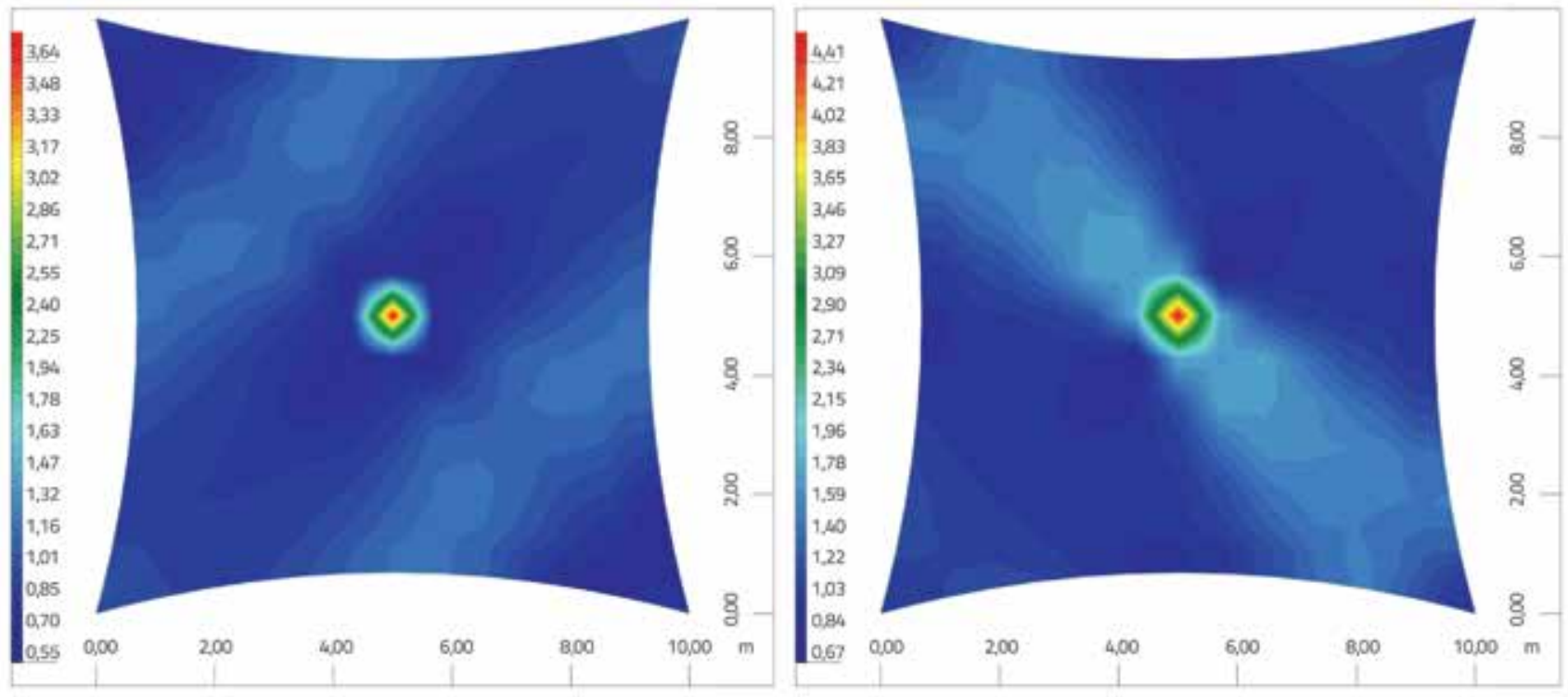

Figure 5. Membrane forces in warp (left) and weft (right) directions under point load of $1 \mathrm{kN}$ at the centre of the membrane (kN/m)

intensity of the tension prestress forces is defined during the form-finding. Recommendations about the intensity of prestress are given in the European design guide [11], along with recommendations for the maximum allowed forces under external loading, depending on material properties. The action of external loads can result in an increase or decrease of membrane forces. Area loads usually have such effects that they increase membrane forces in one direction, and decrease membrane forces in the other direction. This research showed that the point loads have a different effect on membrane forces. The effects of point load of $1 \mathrm{kN}$ on the membrane forces in the centre of the membrane are illustrated in Figure 5.

The intensity of membrane forces of the analysed structure in unloaded state was $1 \mathrm{kN} / \mathrm{m}$ in both warp and weft. The behaviour of membrane forces under point load is similar to the behaviour of membrane deflections under point load. The changes in membrane forces are also highly concentrated around the position of the point load. Even though the whole membrane is affected, a big part of the membrane suffers only minor changes in membrane forces. The same patterns of behaviour are present for every analysed position of the point load. The point loads result in both increase and decrease of membrane forces in both directions. The increase of membrane forces is significant since maximum membrane forces are checked in the structural analysis. However, the decrease of membrane forces is also significant as it can lead to the flutter effect. Figure 6 shows the dependence of maximum membrane forces in warp and weft on the intensity of point load acting at the centre of the membrane. In contrast to behaviour under area loads, both maximum forces in warp and weft increase with an increase in the point load intensity, as shown in Figure 6. A higher increase of maximum forces in weft compared to warp is explained by the orientation of fabric, since weft direction stretches from one high support to the other, and the point load is oriented downwards. The maximum membrane forces for point load acting in each point of the membrane are shown in Figure 7. As Figure 7 shows, maximum forces under point load of $1 \mathrm{kN}$ in warp direction are $4.80 \mathrm{kN} / \mathrm{m}$, and maximum forces in weft direction are 4.57 $\mathrm{kN} / \mathrm{m}$. These two do not occur for the same point load. Different positions of the point loads result in different intensities of the membrane forces.

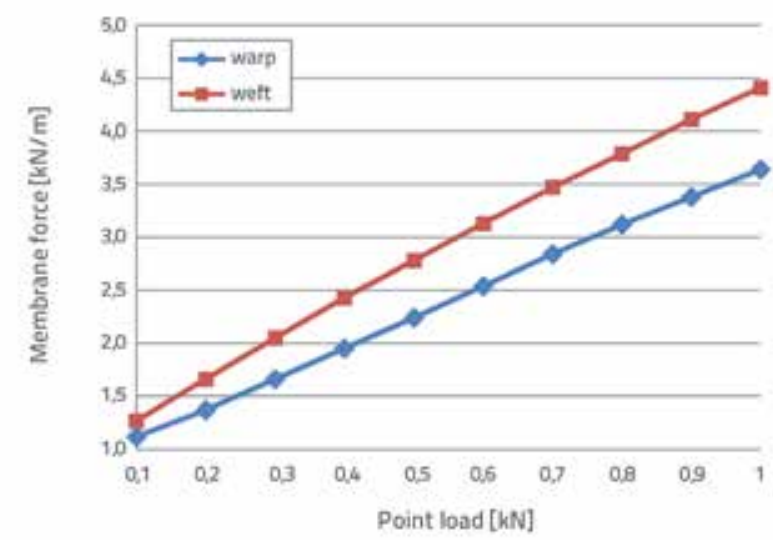

Figure 6. Maximum membrane forces in warp and weft for different intensity of point load acting in the centre of the membrane (kN)

The area load of $0.6 \mathrm{kN} / \mathrm{m}^{2}$ applied over the entire structure analysed in the research changes the intensity of membrane forces, and so the maximum in the warp direction becomes $1.99 \mathrm{kN} / \mathrm{m}$ and the maximum in the weft direction becomes $7.87 \mathrm{kN} / \mathrm{m}$. Higher tension forces in weft than in warp direction are expected since the load is oriented so that it elongates the weft fibres. Had the load been oriented 


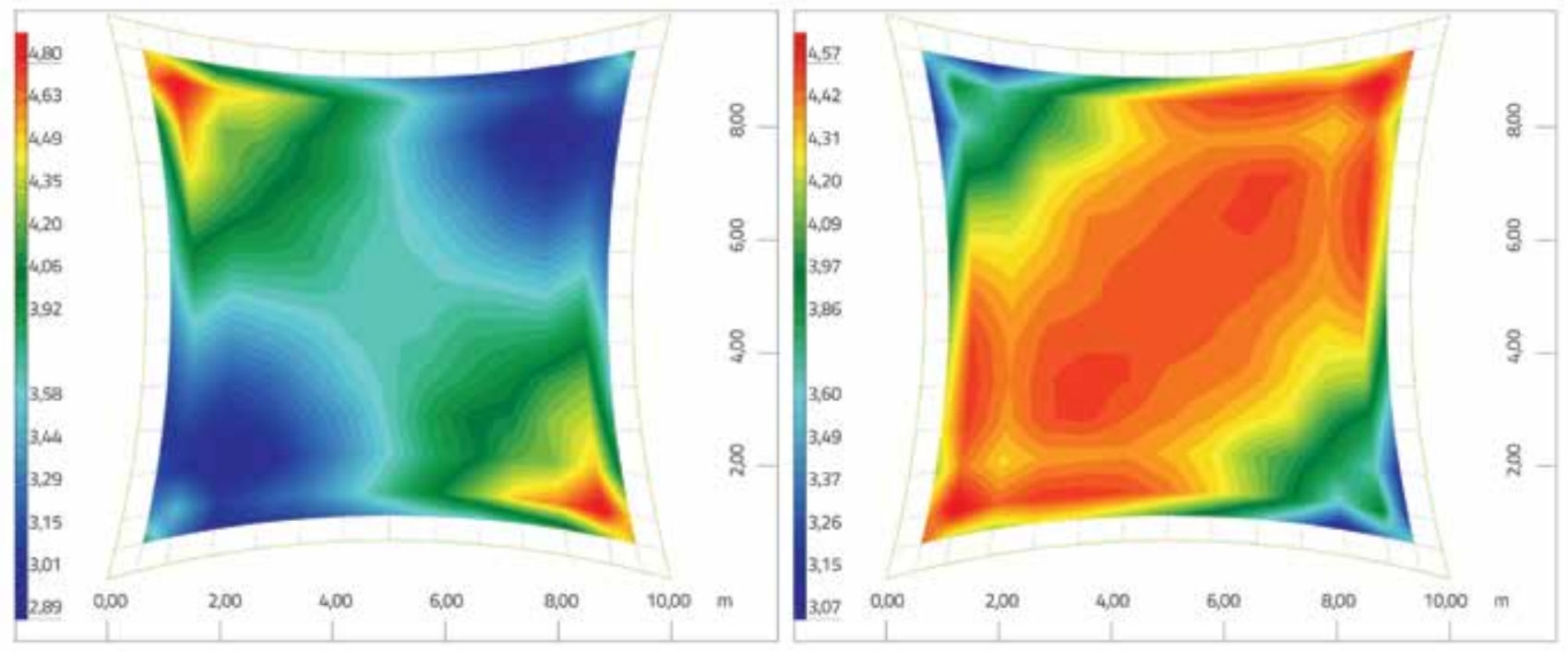

Figure 7. Sensitivity of maximum membrane forces in warp (left) and weft (right) directions under 1 kN point load (kN/m)

vertically upwards the forces in warp would have been higher than the forces in weft. The total area load amounts to more than $50 \mathrm{kN}$, while the point load is only $1 \mathrm{kN}$. However, the resulting change in membrane forces is less than two times larger under the area load. Compared to area load, point loads will produce smaller changes in maximum forces in one direction, and larger changes in the other direction of the fibres. It can be concluded that point loads are significantly more efficient in changing membrane forces. It is also evident that the point loads have an important effect on the change of membrane forces.

\subsubsection{Cable forces}

Edge cables have an important role in prestressing the membrane. During the erection of the structure the membrane is not prestressed directly, but rather through the edge cables. This is done by prestressing the cables, and in such a way the membrane tensioning is achieved. Another way of prestressing the membrane is by moving the supports, so as to introduce once again the tension to the membrane via edge cables. Thus, the cables have a prestressing force of their own. The intensity of the cable prestress is defined in the form-finding step. During the form-finding stage, the curvature of the cable is directly dependent on the intensity of the prestressing force of the cable and of the membrane. An optimum shape of the cables has been researched in the context of structural and aesthetic properties [15]. The cable force is subject to change when external loads act on the membrane. The type and diameter of the cable are selected for the future structure based on the cable forces of the most unfavourable loading case during structural analysis. Table 1 shows the highest cable forces when the analysed structure is loaded with point loads in the marked points.

Point load positions are selected in such a way to represent the typical membrane behaviour, keeping in mind that the analysed structure is double symmetric to its diagonals. Supports B and D are lower supports. The cable force in the

Table 1. Maximum cable forces under point load

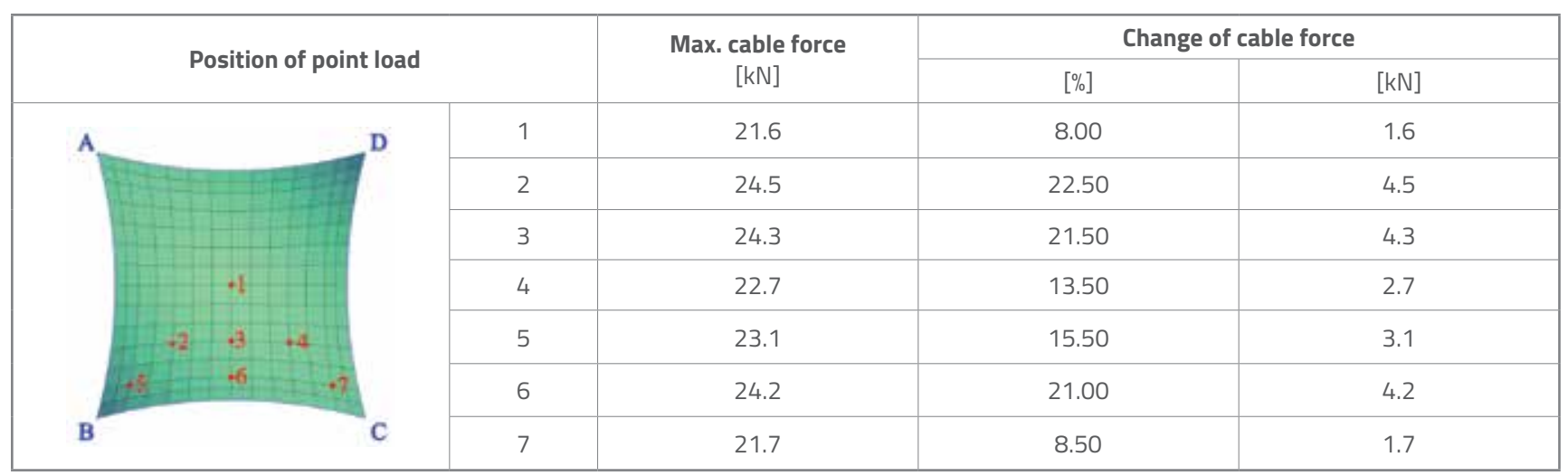


unloaded state is $20 \mathrm{kN}$. As the results show, the loading by point loads also has an impact on the change of intensity of force in the edge cables. The increase in force intensity is not large, and the maximum increase is $4.5 \mathrm{kN}$ or the $22.5 \%$ of the original force intensity. This may seem like a significant change in terms of percentage but, when compared to usual area loads, this effect is minor. For illustration, the area load of $0.6 \mathrm{kN} / \mathrm{m}^{2}$ applied over the entire structure results in the cable force increase to the values of approximately 70 $\mathrm{kN}$, which is a change of over $250 \%$. The cables are usually dimensioned according to load cases that include area loads. All nodes of the analysed structure are checked for the effects of point loads on cables, and all of them have very little impact on the increase of cable forces. The point loads would have to be unexpectedly large to surpass the effects of area loads. It can therefore be concluded that point loads do not have a significant effect on the change of cable forces, and do not have an important role in the dimensioning of cables, especially when compared to typical area loads. The point loads produce local changes of the membrane geometry and membrane forces due to the flexibility of the membrane, but the changes of forces in cables are minor since they are more rigid and prestressed.

Membrane structures have at least four non-planar point supports, with more complex structures having a greater number of supports. Linear supports are sometimes used as another option for supporting membrane structures, but they result in larger cross sections, which is not in line with the lightweight character of the membranes. All loads are transferred from the membrane via edge cables to the point supports. This applies to the external loads, but also to the prestress and self weight. The smaller the forces in supports, the lighter the supporting structure will be, and the supporting structure is fundamental to the efficiency, cost and elegance of a lightweight structure [16]. Point loads generally have a small amount of total load and, therefore, they should not have a significant impact on the support forces. The representative results of the research concerning support forces are given in Table 2.
The intensity of support reactions in all four supports when there is no external load acting amounts to $35.8 \mathrm{kN}$. When the point load is acting on the structure, the support reactions change, and the directions of support reactions change as well. Maximum support reactions for seven different positions of the point load are given in Table 2 . As the results show, there are no significant changes in the intensity of the support force. The largest change is $4.3 \mathrm{kN}$, which is about $12 \%$ of the original intensity of the support force. This increase does not have an important effect on the support structure. The change of direction of reactions is very small for all point load positions that are along the diagonals of the structure. Somewhat larger changes of direction are present at positions 3 and 6 , and even these values are small. This result was expected based on the analysed results of the change in cable forces. Since the support force is a resultant of cable forces acting in that support, and the increase of cable forces is not significant, the expected change of support force is also not large. The resulting support force produced by the area loads has a much higher intensity than the one produced by the point loads. Area loads of $0.6 \mathrm{kN} / \mathrm{m}^{2}$ applied over the entire structure result in support forces of over 120 $\mathrm{kN}$, which is an increase of about $250 \%$. It is interesting to point out that the point load of $1 \mathrm{kN}$ can produce the increase of support force of more than $4 \mathrm{kN}$.

\subsection{Effects of point loads compared to area loads}

Maximum effects of the point load of $1 \mathrm{kN}$ were compared to the area load of $0.6 \mathrm{kN} / \mathrm{m}^{2}$. The application area of the area load was varied, so that the application area was 1.7, 15.3, 42.4 and $84.4 \mathrm{~m}^{2}$. The resultant forces of these loads are 1.0, $9.2,25.4$, and $50.6 \mathrm{kN}$, respectively, all of them positioned in the centre of the structure. The results of the comparison between point loads and area loads are summed up in Figure 8. The lower part of Figure 8 illustrates the application area of the analysed area loads. As Figure 8 shows, the effects of area load generally increase with an increase in the application area. One exception occurs in maximum change

Table 2. Maximum support force under point load

\begin{tabular}{|c|c|c|c|c|c|c|c|c|c|}
\hline \multirow{2}{*}{\multicolumn{5}{|c|}{ Position of point load }} & \multicolumn{2}{|c|}{ Max. support reaction [kN] } & \multicolumn{2}{|c|}{ Change of max. support force } & \multirow{2}{*}{$\begin{array}{l}\text { Change of max. support } \\
\text { react. direction } \\
{\left[^{\circ}\right]}\end{array}$} \\
\hline & & & & & Ležaj & Sila & {$[\%]$} & {$[\mathrm{kN}]$} & \\
\hline \multirow[t]{6}{*}{ A } & & & D & 1 & A. C & 38.1 & 6.42 & 2.3 & 0.20 \\
\hline & & & & 2 & $\mathrm{~B}$ & 40.1 & 12.01 & 4.3 & 0.01 \\
\hline & & & & 3 & A & 39.9 & 11.45 & 4.1 & 2.55 \\
\hline & & +1 & & 4 & A & 39.9 & 11.45 & 4.1 & 0.16 \\
\hline & +2 & 4 & .4 & 5 & $\mathrm{~B}$ & 39.3 & 9.78 & 3.5 & 0.71 \\
\hline & & +6 & +7 & 6 & A & 39.8 & 11.17 & 4.0 & 2.50 \\
\hline B & & & C & 7 & A & 38.3 & 6.98 & 2.5 & 0.08 \\
\hline
\end{tabular}


of geometry when the application area is increased to the whole structure. In this case a small decrease can be noted. This is explained by the fact that some of the unloaded parts of the structure are actually being lifted, thus allowing the loaded parts to get lower than in the case when the whole structure is loaded, and all nodes get lower with somewhat smaller displacement. When compared to these area loads, point loads generally exhibit smaller values for the monitored parameters. It is interesting to point out that the smallest area load has the same resultant force as the point load. Nevertheless, the point load produces bigger changes in all four monitored parameters compared to this area load. This leads to the conclusion that point load is more efficient in changing the membrane geometry, membrane forces, cable forces, and support reactions, compared to the same load applied as area load over small area. However, the real life situation of snow load is best represented by the area load applied over the whole structure. This load has more than 50 times more load than the point load of $1 \mathrm{kN}$. Compared to this area load, point load produces comparable effects with respect to maximum geometry change and maximum change in membrane forces, despite the large difference in total load. The maximum geometry change and the maximum changes of membrane forces under point load occur exactly at the point where the point load is applied. Maximum changes in cable forces and support reactions show different behaviour, since with regard to these two aspects the point load produces far less effect than the heavier area load. The point load also has a minimum influence on the change of direction of support reactions.
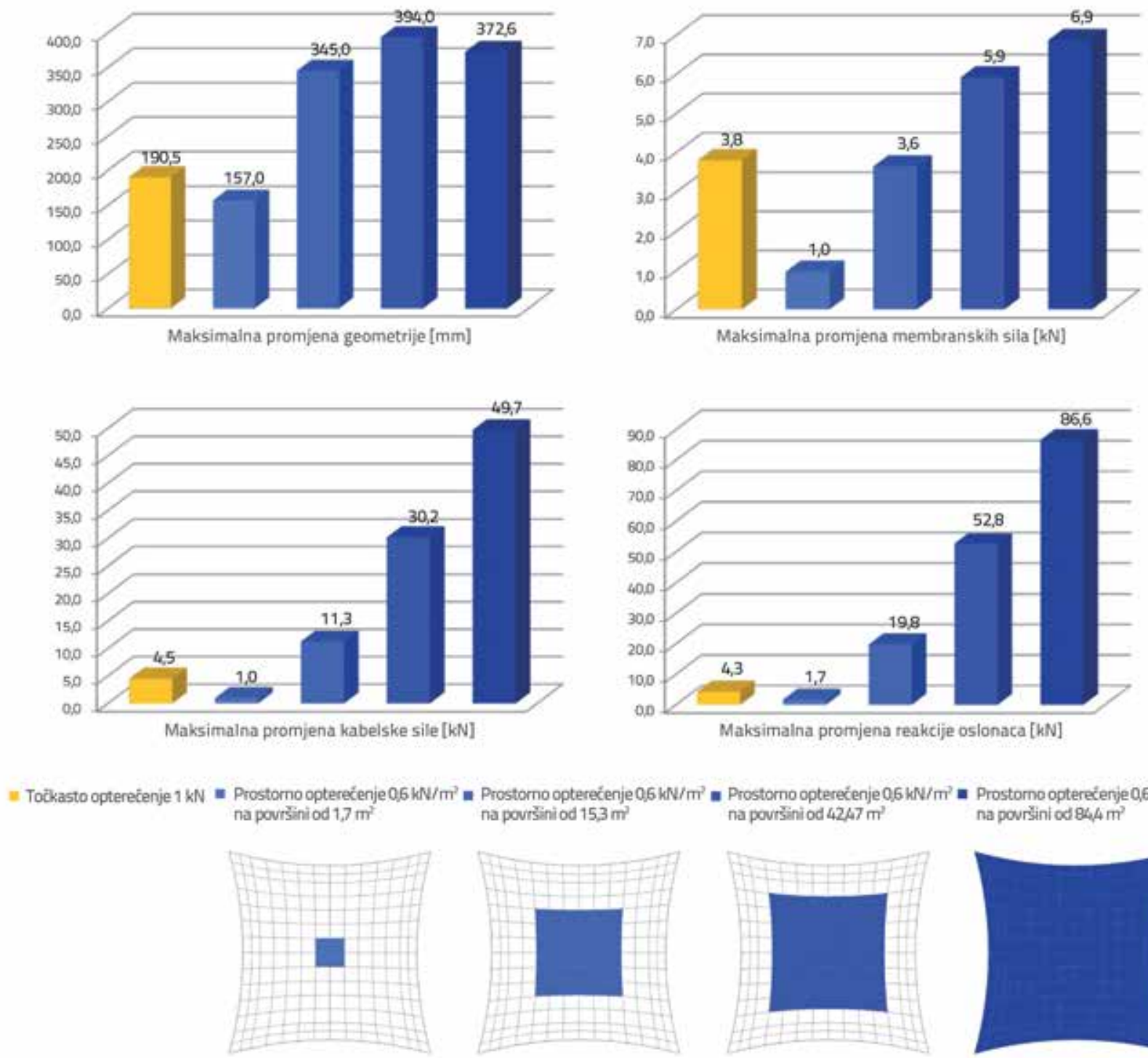

Prostorno opterećenje $0.6 \mathrm{kN} / \mathrm{m}^{2}$ na poviršini od $42 / 47 \mathrm{~m}^{3}$

Prostorno opterecenje 0.6 kN/m na površiniod $844 \mathrm{~m}$ ?

Figure 8. Maximum effects of point load of $1 \mathrm{kN}$ compared to area load of $0.6 \mathrm{kN} / \mathrm{m}^{2}$
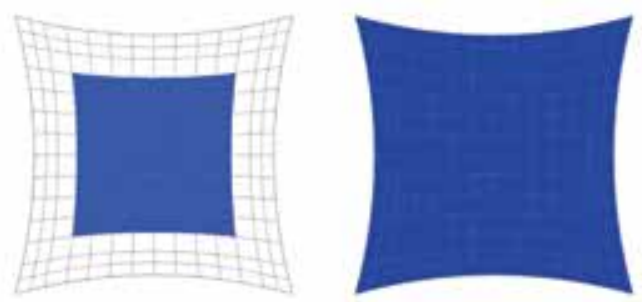


\section{Conclusion}

In this research, a numerical model of a typical membrane structure is analysed for the effects of point loads. Four different parameters of the structure have been analysed: maximum changes in geometry, maximum changes in membrane forces, maximum changes of cable forces and maximum change of support reactions. All nodes of the structure have been loaded one at a time with point loads of $1 \mathrm{kN}$ in order to obtain the maximum effects on the monitored parameters. The structure has also been independently loaded with an area load of $0.6 \mathrm{kN} /$ $\mathrm{m}^{2}$ in order to compare the effects of point load and area load. The research results show that point loads have an important effect on the changes in geometry and membrane forces, while the changes of cable forces and support reactions are not significant compared to the area load of $0.6 \mathrm{kN} / \mathrm{m}^{2}$ acting over the entire structure. The reason for such behaviour of membrane structures under point loads lies in the fact that the properties of membranes differ greatly from properties of other materials including steel and steel cables. Point loads indeed cause very local effects on membranes, due to the flexibility of the material, but the magnitude of these effects is significant. Membranes have no bending or compression stiffness, and counteract the external loading by change of geometry and change of membrane forces. However, both the changes in geometry and the changes in membrane forces are highly concentrated around the position of the point load. Since the membrane material suffers large strains, and the amount of load in point loads is not high, only a small part of the effects is transferred to prestressed cables, which resist the influence of point loads much better than membranes. As a consequence, cable forces and the support reactions do not suffer large increases of intensity or large changes in reaction directions under the action of point load.

The findings of this research reveal that it would be beneficial to further investigate the possibility of introducing the point loads into structural analysis. So far, only area loads have been taken into account in structural analysis, and the effects of point loads are often neglected. This research shows the shortcomings of this approach and concludes that the effects of point loads should also be considered in structural analysis. The need for monitoring the effects of point loads will most likely appear during structural analysis, especially in the aspect of geometry changes and changes of membrane forces produced by the action of point loads.

\section{Acknowledgements}

The authors would like to thank Dr. Pedro Munoz for sharing his views and his helpful discussions, and Dr. Petar Mitkovic, Dean of the Faculty of Civil Engineering and Architecture of the University of Nis, for his generous support.

\section{REFERENCES}

[1] Bletzinger, K.U., Wuncher, R., Daoud, F., Camprubi N.: Computational methods for form finding and optimization of shells and membranes, Computer methods in applied mechanics and engineering, 194 (2005), pp. 3438-3452, http://dx.doi. org/10.1016/j.cma.2004.12.026

[2] Fresl, K., Gidak, P., Vrančić, R.: Generalized minimal nets in form finding of prestressed cable nets, Građevinar, 65 (2013) 8, pp. 707720.

[3] Brew, J.S., Lewis, W.J.: Spline-based and stress-monitored patterning of fabric structures, Computers \& Structures, 119 (2013), pp. 203-214, http://dx.doi.org/10.1016/j.compstruc.2012.11.013

[4] Koprivec, Lj., Zbašnik-Senegačnik, M., Kušar, J.: Uporaba tehničkih tekstila u visokogradnji, Građevinar, 58 (2006) 11, pp. 899-907.

[5] Ambroziak, A., Klosowski, P.: Mechanical properties for preliminary design of structures made from PVC coated fabric, Construction and Building Materials, 50 (2014), pp. 74-81, http://dx.doi. org/10.1016/j.conbuildmat.2013.08.060

[6] Milosevic, V.: Dependence of Membrane Deflection on the Position and Intensity of Point Loads, Structural Engineering International, 1 (2015), pp. 20-25, https://doi.org/10.2749/10168 $6614 \times 14043795570372$

[7] Selvadurai, A.P.S.: Deflections of a rubber membrane, Journal of the Mechanics and Physics of Solids, 54 (2006), pp. 1093-1119, http://dx.doi.org/10.1016/j.jmps.2006.01.001

[8] Milosevic, V., Markovic, B., Stojic, D.: Effects of Different Prestress Intensities on the Displacement of Membrane Structures under Point Loads, Facta Universitatis, Series: Architecture and Civil Engineering, 14 (2016), pp. 311-318, http://dx.doi.org/10.2298/FUACE1603311M
[9] Milosevic, V., Markovic, B.: Uticaj oblika osnove membranskih konstrukcija na pomeranja pod dejstvom sile, Tehnika, LXXI, pp. 187-193, 2016, http://dx.doi.org/10.5937/tehnika1602187M

[10] American Society of Civil Engineers, Tensile Membrane Structures, Standards ASCE/SEI 55-10, Structural Engineering Institute, 2010.

[11] Forster, B., Mollaert, M.: European Design Guide for Tensile Surface Structures, TensiNet, Brussels, 2004.

[12] Sofistik, Version 2012, Sofistik AG, Oberschleissheim, 2012.

[13] Tsiatas, G.C., Katsikadelis, J.T.: Large deflection analysis of elastic space membranes, International Journal for Numerical Methods in Engineering, 65 (2006), pp. 264-294, http://dx.doi.org/10.1002/ nme.1499

[14] Gosling, P.D., Bridgens, B.N., Zhang, L.: Adoption of a reliability approach for membrane structure analysis, Structural Safety, 40 (2013), pp. 39-50, http://dx.doi.org/10.1016/j. strusafe.2012.09.002

[15] Bridgens, B., Birchall, M.: Form and Function: The Significance of Material Properties in the Design of Tensile Fabric Structures, Engineering Structures, 44 (2012), pp. 1-12, http://dx.doi. org/10.1016/j.engstruct.2012.05.044

[16] Gosling, P.D., Bridgens, B.N., Albrecht, A.: Analysis and design of membrane structures: Results of a round robin exercise, Engineering Structures, 48 (2013), pp. 313-328, http://dx.doi. org/10.1016/j.engstruct.2012.10.008 